\title{
Never had it but now I have to Teach it: A Study into how Primary Teachers Implemented a New Curriculum Requirement in Teaching Practice
}

\author{
Steven S. Sexton \\ College of Education, University of Otago, Dunedin, New Zealand \\ *Corresponding Author: steven.sexton@otago.ac.nz
}

\section{ABSTRACT}

In 2017, a change to the national curriculum of New Zealand required primary teachers to implement a new component into the Technology area of The New Zealand Curriculum. This was to be fully implemented by the start of the 2020 school year. However, unless this was a personal area of ability, no primary teacher in New Zealand has been trained or prepared for this new addition. This study reports on how one school worked to implement this new requirement into their teaching practice. This study noted that for the participating teachers, teaching an unknown area of the curriculum required emotional work, political work, and pedagogical work. Over the course of the 2019 school year, these teachers in collaborative professional development (PD) sessions explored, experimented with, and enacted digital technology. Results from this study showed that students' learner was enhanced through teachers' meaningful and purposeful integration of digital technology in their programs of learning. This study offers insight into how primary teachers were able to work in authentic collaborative relationships to support each other in how to implement a new curriculum requirement that was not supported by any ministerial PD.

KEY WORDS: primary education; technology; digital technology; professional development

\section{INTRODUCTION}

T

n 2017, the New Zealand's Ministry of Education released an update to the National Curriculum, making digital technology compulsory for curriculum levels $1-5$ (equivalent to the first ten years of a student's education). Schools are expected to implement these revisions into their programs of teaching and learning for the start of the 2020 school year. Specifically, primary teachers (school years 1-6) are going to be expected to be able to contribute to students developing as digital citizens and users of digital technologies.

Technology is one of eight curriculum areas that initial teacher education (ITE) addresses in primary teacher education (Ministry of Education, 2007). The current New Zealand ITE primary education programs were designed and approved to support student teachers being prepared to enter the teaching profession under the 2007 curriculum document. As such, ITE student teachers are exposed to Technology in their program of study usually in combination with Science in one curriculum paper (University programs are divided into papers or courses/classes). In many ITE programs, student teachers are able to select Technology as an additional curriculum area of study. However, the Ministry of Education's changes to the Technology curriculum to position Digital Technology explicitly as part of Technology has not been part of any New Zealand ITE program for the past thirteen years (Ministry of Education, 2007) nor part of the previous Technology curriculum document (Ministry of Education, 1995). Therefore, most of New Zealand's primary school teachers have had no preparation for the implementation of this new teaching and learning requirement. This study aimed to identify how effective were tools, toys, and technologies for teachers being able to implement this new curriculum requirement in their classroom teaching.

\section{THEORETICAL FRAMEWORK}

This study used Deleuze and Guattari (1988) notion of "assemblage" to discuss how forms of teacher's emotional, political, and pedagogical work intersect with school-based discourses, curriculum policy, and institutional expectations. These interactions influence their decisions, beliefs, and actions when teaching a previously unknown area of the curriculum. This study noted that for the participating teachers, teaching an unknown area of the curriculum required emotional work due to undertaking an area of unknown curriculum while continuing with their day-to-day teaching. These teachers were called upon to undertake political work when implementing a political policy without any additional learning or support by New Zealand's Ministry of Education. Finally, these teachers experienced pedagogical work in using both dialogic methods and digital toys. These teachers needed to navigate content-specific terminology and codable toys with students experiencing frustration and anxiety. This positioned them in an 
assemblage of complex emotional, political, and pedagogical work as the classroom teacher.

For this study, Deleuze and Guattari (1988) construct of "assemblage" highlights the ongoing interactions among discourses, personal, and institutional histories. Assemblages as a theoretical framework are suitable for this study as they have multiple elements that intersect in a non-hierarchical order. Furthermore, as assemblages are both non-linear and constantly evolving their complexity reflects what Fraser (2016) called, "the work and artistry of teaching" (p. 57). In this study, assemblage mediates the capacities of teachers as both individuals and as a group for acting and being acted upon and in so doing contributes to the maintenance of the status quo or the emergence of new forms of thinking and action. Viewed through an assemblage lens, teachers' work in teaching can be understood as operating within a complex intersection of beliefs, values, expectations, and practices that are in a state of constant flux, creating both openings and barriers that influence the possibility of action.

\section{TECHNOLOGY IN NEW ZEALAND EDUCATION}

The Ministry of Education has set out progress outcomes to guide schools and teachers in planning how to incorporate this new subject area. Computational thinking for digital technologies Progress Outcome 1 is to be achieved by the end of Curriculum Level 1, which students should achieve by the end of Year 2 (students aged 7 years old). Students will:

In authentic contexts and taking account of end-users, students use their decompositions skills to break down simple noncomputerized tasks into precise, unambiguous, step-by-step instructions (algorithmic thinking). They give these instructions, identify any errors in them as they are followed, and correct them (simple debugging). (Ministry of Education, 2017. p. 11)

Progress Outcome 2 is to be achieved in Curriculum Level 3, which includes students in Years 5 and 6 (students aged 1011 years old). By Year 6, students will:

In authentic contexts and taking account of end-users, students give, follow, and debug simple algorithms in computerized and non-computerized contexts. They use these algorithms to create simple programs involving outputs and sequencing (putting instructions one after the other) in age-appropriate programming environments. (Ministry of Education, 2017, p. 11).

This study sought to address the research question, "How effective for teachers was a series of scaffolded professional development (PD) and classroom lessons on coding with codable toys in addressing the requirement to implement a new subject area that had not been a part of their initial teaching and learning education program or any in-service PD?" Coding with codable toys, such as the Code-a-Pillar and the Code and Go Robot Mouse, offers opportunities for teachers and students to break down simple non-computerized tasks into step-by-step instructions and then identify any errors in them (Progress Outcome 1). These algorithmic thinking activities are then built upon with more advanced coding using codable toys such as Micro: bits to support teacher and students giving, following, and debugging simple algorithms in computerized contexts (Progress Outcome 2).

Schools and teachers had until the start of the 2020 school year to implement this new content into their school's teaching and learning programs. In New Zealand, the 2020 school began between January 27 and February 7. New Zealand schools are given some flexibility in their start date. This study offered the participating teachers and their students the opportunity to explore how effective a program of teaching and learning on coding with codable toys was in implementing this new area of the curriculum (Garbett and Ovens, 2015) before the 2020 school year.

\section{METHODOLOGY}

As stated, assemblages intersect in a non-hierarchical order. As such, this study was designed as a collaboration between this study's researcher and the participating school. Rubin (2009) notes, "a collaboration is a purposeful relationship in which all parties strategically choose to cooperate to achieve shared or overlapping objectives" (p. 2). This study was a purposeful relationship between a university academic working in ITE and a partner school. Both parties have had no training or PD in how to implement digital technology into their teaching practice. Therefore, both parties came to this study as co-learners in an attempt to explore and experiment with digital tools, toys, and technologies.

This study was designed to be exploratory and illuminatory (Punch and Oancea, 2014). It used qualitative data. The primary data collection was through teacher and student comments about how they experienced coding with codable toys as effective teaching and learning, gathered from observations of lessons (Miles and Huberman, 1994). The study sought different levels of enquiry and the ability to explore different aspects of the same problem. First, qualitative analysis of the lessons using coding with codable toys. Second, qualitative analysis of how the participating teachers and students perceived the use of coding with codable toys as effective teaching and learning opportunities.

The proposed study investigated the effectiveness of coding with codable toys through a series of sequenced lessons for each class. Initially, the researcher worked with the school teachers in traditional PD sessions before the start of the school year to introduce coding with codable toys so that they were able to participate as co-facilitators of teaching and learning with their students. Research has identified teachers as the crucial factor in learning and how materials must be used, "to supplement and amplify what the teacher does" (De Bruyckere et al., 2016. p. 13). It was anticipated that both the teachers and students would become more familiar with coding with codable toys through these lessons. 


\section{Participants}

The participating school was purposively selected. First, the research study sought to include the entire teaching staff of a school rather than working with only one or two teachers from a range of schools. Research has identified issues in PD that includes only a limited number of teachers from a school and then the school's ability to implement effectively new initiatives (Gore et al., 2017; Korthagen, 2017). Second, a teaching staff that generally reflected the average primary teacher demographics in New Zealand in 2019: i.e., a 53-yearold Pākehā (white European descent) middle-class female teacher who has been teaching for 15 years (Education Counts, n.d.). In 2019, the participating school (School) consisted of five classrooms, of which one is the Assistant Principal and another is the Deputy Principal, the schools' principal, and 115 students. The students range from New Entrant (NE) (in New Zealand students are able to begin schooling on the day they turn 5 , but must begin formal school by their 6 th birthday starting the school year in Year 1), to Year 1, 2, 3, 4, 5, and 6. The School was predominately Pākehā with 20 students selfidentified as Māori (indigenous New Zealand) and another 15 students from various other ethnicities. The teaching staff was all female ranging in age from mid-twenties into the late $50 \mathrm{~s}$. The newest qualified teacher had been teaching for only a few years while the most senior teacher had been teaching for over 30 .

This study was granted ethics approval by the researcher's university ethics committee. The school was approached for inclusion in 2018. The School's principal then took this study to the School's Board of Trustees to gain permission for the study to begin with the start of the 2019 school year. Informed consent to participate was granted by all teaching staff. After Board of Trustee approval and teacher consent to participate in the study, the School's parents were notified about the study to obtain permission for their child/children's participation at the start of the school year.

\section{The Intervention}

The participating teachers and their students were introduced to Code.org. First, Code.org is a free online source of digital technology support for classroom teachers. Second, it has scaffolded lessons targeted to primary aged students. Third, it includes teacher notes and supporting content to facilitate teachers being able to implement coding and digital technologies in the classroom. Finally, it supports teachers in being able to document individual student progress. Code.org was then supplemented with codable toys: Code-a-pillar, Code and Go Robot Mouse, and Micro:bits.

To support the student participants, their classroom teachers participated in activities as in-service PD before its implementation in the classroom. To support the teacher participants, each teacher was provided a release from teaching during the school day to plan, prepare, participate, and experience the activities before their students as part of ongoing PD (Armour and Yelling, 2007; Garet et al., 2001). As each year group had a series of approximately 15 sequenced lessons, this study was planned to be delivered over the length of the 2019 school year (in 2019, the School began on February 4 and ended December 16). Over the course of the study, teachers were released for 8 full days, approximately once a month. This provided teachers time out of class to plan, prepare, participate, and experience upcoming activities.

Code.org activities can range from 10 min to well over an hour, depending on the age of students and their engagement in the activity. Initial activities allowed teachers and students to become familiar with Code.org and before engaging in teaching and learning opportunities of coding with the codable toys. As noted in a 2009 meta-analysis of blending technology with teaching and learning (Means et al., 2009), these lessons were designed to support improved student learning.

The aim of this study was to investigate how effective a series of scaffolded lessons, tailored to each year group, on coding with codable toys was in addressing the requirement to implement a new subject area that had not been a part of any of the participating in-service teachers' ITE programs or any in-service PD. These lessons included whole classroom and small group discussions. These discussions led by the teachers were based on semi-structured interviewing, as this does not pre-determine all of the questions that would be included in the study. The classroom teachers experienced the lessons as part of an ongoing PD program before their students and participated in collaborative discussions about the activities before their students experiencing the activities. These discussions focused around the following question prompts:

- How do you think this activity/lesson went? Why do you think that?

- What about Code-a-pillar/Code and Go Robot Mouse/ Micro: bits did you enjoy?

- How did the Code-a-pillar/Code and Go Robot Mouse/ Micro: bits help you understand step-by-step instructions/ debugging?

- Why did your Code-a-pillar/Code and Go Robot Mouse/ Micro: bits behave the way it did?

- How are you feeling about coding?

As digital technology has been given a Ministerial directive to become part of every primary classroom in New Zealand, the lessons were taught as part of normal classroom activities. As this study was exploratory to determine what tools, toys, and technologies were suitable for the School's implementation, these lessons were predominantly hands-on but designed to engage the students in working toward the Progress Outcomes 1 and 2 of the new Technology in the New Zealand Curriculum document (Ministry of Education, 2017).

\section{RESULTS AND DISCUSSIONS}

\section{First Intersection - What are we Supposed to do?}

This study began on January 28, 2019, with an orientation to Digital Technology (Ministry of Education, 2017) and The New Zealand Curriculum (Ministry of Education, 2007) during a 
teacher only day before the start of the school year. As stated, when viewed through an assemblage lens, teachers' work in teaching can be understood as operating within a complex intersection of beliefs, values, expectations, and practices that are in a state of constant flux, creating both openings and barriers that influence the possibility of action. For all of these teachers and the researcher, coding was something we had not learned or received any PD. To assuage initial concerns, these teachers needed to know we were not being asked by the Ministry of Education to teach computer programming. While this is a legitimate option that some schools and teachers have been offering as extension or extra-curricular, it is not a requirement. We need our students first to be able to break down simple non-computerized tasks and identify errors and correct them (Ministry of Education, 2017). Then, as students advance their understanding, they are able to give, follow, and debug computerized and non-computerized algorithms (Ministry of Education, 2017). The lack of any PD from or by the Ministry of Education created ambiguity, confusion, and concern in these teachers as to what was being asked of them by the Ministry. The unpacking of what Digital Technology is and means in Primary education was the first intersection of teachers' beliefs, values, and expectations that needed to be negotiated. This first day established the open and honest sharing of ideas "without fear of repercussions, punishment, or isolation" (Rubin, 2009. p. 13) needed for this study's collaborative relationship to proceed into these teachers' practice.

\section{Second Intersection - Problem of Enactment}

Over the length of Term 1 (schools in New Zealand generally operate on four 10-week terms per year with a 2-week break between each term), teachers were to begin implementing Digital Technology into their teaching programs. The teachers decided that 1-session per week would be a good starting point. When asked to explain how and why this would be a good starting point, Alice (all names are pseudonyms, the Year 3 teacher) stated that this would let her feel comfortable enough to bring this into the classroom. Five of her colleagues agreed. Only Beth, the newest teacher in the school, stated she could see herself doing this every day of the week in her class and make it the core subject area of her integrated units for the entire year. In their first in-school PD session early in Term 1, we discussed issues around what Kennedy (2016) referred to as the "problem of enactment" which she defined as "a phenomenon in which teachers can learn and espouse one idea, yet continue enacting a different idea, out of habit, without even noticing the contradiction" (p. 947). Beth's desire to implement more digital technology was not cause for her colleagues. Teachers work together in the school for the benefit of students. In this school (arguable like many schools), the teachers support and encourage each other. New Zealand promotes various new initiatives in an attempt to build capacity within schools. The principal in discussions about this initiative of bringing in digital technology noted about her colleagues, "they are very encouraging of each other and always very willing to put their all into a new initiative."
A collaborative relationship requires not only the purposeful relationship in which all parties choose to cooperate but also have shared or overlapping objectives. The shared objective of the 2019 year was for the School to investigate what tools, toys, and technologies were appropriate for them to implement this new curriculum area. This meant that the teachers were going to have to step out of their comfort zone for a new learning area to them. By the end of Term 1, all the teachers reported, "This is new to most students and they are enjoying the activities." The teachers realized that a significant portion of the students' learning did not require digital devices noting, "Most of the learning is off-line. The toys are just supplemental."

One of the biggest concepts students needed to grasp as they begin to understand algorithmic thinking is how to identify and then solve a problem in their step-by-step instructions. It became evident across the school how important perspective was when students gave instructions. Barbara noted the advantage of off-line activities as students were "able to do this on the mat with students acting as robots. We found left and right is really dependent on perspective." In an activity, the programmer was telling her robot what to do to get from one square to another around an obstacle (children were using a large grid of $30 \mathrm{~cm} \times 30 \mathrm{~cm}$ squares on the classroom floor). The programmer was becoming increasingly upset as her robot would not go in the direction she said. When the class was questioned on what advice they would give the programmer, the students behind the programmer noted she was giving the correct directions on where to go while the students sitting behind the robot disagreed. It was only when the programmer and robot were facing the same direction that the step-by-step directions became clear.

At the end of Term 1, Beth moved to a new school and Laura was hired to replace her. Laura like her colleagues had not digital technology training or PD.

\section{Third Intersection - Prescription versus Insight}

Kennedy (2016) noted that PD programs traditionally are prescriptive, as prescriptive PD works to ensure that teachers do what the provider tells them to do. Kennedy goes on to highlight that this is the norm for teachers as they often have new policies or practices dictated to them. For example, the New Zealand Ministry of Education directing all primary schools to implement a new curriculum area. Kennedy reported that prescriptive PD may address an area of concern but may result in other areas of concern. Unlike prescriptive $\mathrm{PD}$, insight $\mathrm{PD}$ programs necessitate teachers making the decisions as a means to alter their future thinking and behavior. As Kennedy (2016) summarized, "Prescriptions tend to offer universal guidance, allowing teachers very little discretionary judgment... Insights encourage even more professional judgment, helping teachers learn to "see" situations differently and to make their own decisions about how to respond." (p. 956). This study implemented insight PD. 
Over the course of the year, these teachers worked in collaboration with colleagues and the researcher to determine what digital tools, toys, and technology worked for them and their students. These teachers saw integration as a natural way to bring in this new learning area. For example, the Year NE, 1, and 2 classes used the Code-a-pillar with the storybook The Very Hungry Caterpillar (Carle, 1994). Integration of literacy was through the reenacting of the story with the Code-a-pillar. Each piece added to the Codea-pillar resulted in a different motion. Through a series of up to eleven different connections, the students develop a sense of stepby-step instructions (Progress Outcome 1). Similarly, students in Years 3-6 worked with a Code and Go Robot Mouse that moves a set distance or turns in a set direction by pressing control buttons on the mouse. Unlike the Code-a-pillar (each attached piece is a different instruction), the Code and Go Robot Mouse is able to be programmed with up to 40 commands at a time for a more complex set of step-by-step instructions as a means to transition from Progress Outcome 1 into Progress Outcome 2, Figure 1.

In discussions about the use of digital toys in teaching and learning, the teachers made the following comments:

Variety was good, something a bit different. Kids able to design own courses and code toys (Code and Go Robot Mice) to complete set courses (Diane Year 5/6).

Code-a-pillar is just a toy, does not see any value in it otherwise. Mice were great - kids loved them, so many different things could be done with them and they were fantastic to begin the whole "debugging" process. Tangible (Alice).

Code-a-pillar, kids enjoyed playing with it but not really able to extend. Mice really good but need separate resources, e.g., mats/grids (Amy).

The teachers were exposed to Code.org as a resource as it provides teachers with a series of lessons to include a guide in estimated time for delivery. Initially, these teachers thought they could just download each lesson, print off any handouts or templates required, and go into the classroom with the pre-set lessons. Code.org became a resource to use not a prescribed program to deliver:
Very nice thank you. Without them, I would have been floundering. Good progressions (Diane).

Invaluable and gave me an opportunity to practice well before. When we got stuck on one, then I could pull up and work through with kids (Alice).

Perfect for teachers and students. Really enjoyed using the Mice resources and will again (Barbara).

The Micro: bits were just way too hard to handle. We are not ready for those yet (Diane).

NEs - we started well and children enjoyed it, but as the year went on with new clusters of children, it started to get a bit hard (Amy).

Integration of teaching subjects is often touted as a means to address issues in teaching both here in New Zealand and internationally (e.g., ERO, 2012; Ministry of Education, 2007; Yurdakul, 2015). Fraser (2013) provides a comprehensive account of how integration is not the same as a thematic unit. Upon reflection, these teachers acknowledged that they were more thematic in their initial planning than integrated. What they wanted to call integrated curriculum was, in fact, thematic planning as they sought to preplan and prepare their activities as syndicate groups. The Code.org resources they initially saw as a predetermined and prescribed assessment tasks to be used as indicated in the suggested series of lessons. Term 1 started with teacher-directed activities, as this provided them with a sense of security in implementing a new curriculum area. It was the students stumbling and confusion that allowed the shift into integrated units rather than thematic units. The teachers shifted their practice from subjects areas slotted into the digital literacy to subject areas included when they supported the digital technology learning:

When it got too tricky for my younger ones online, then we could have a break and also front-load for the lacking skill (Alice).

Using real objects or themselves always helps the kids understand trickier concepts (Laura).
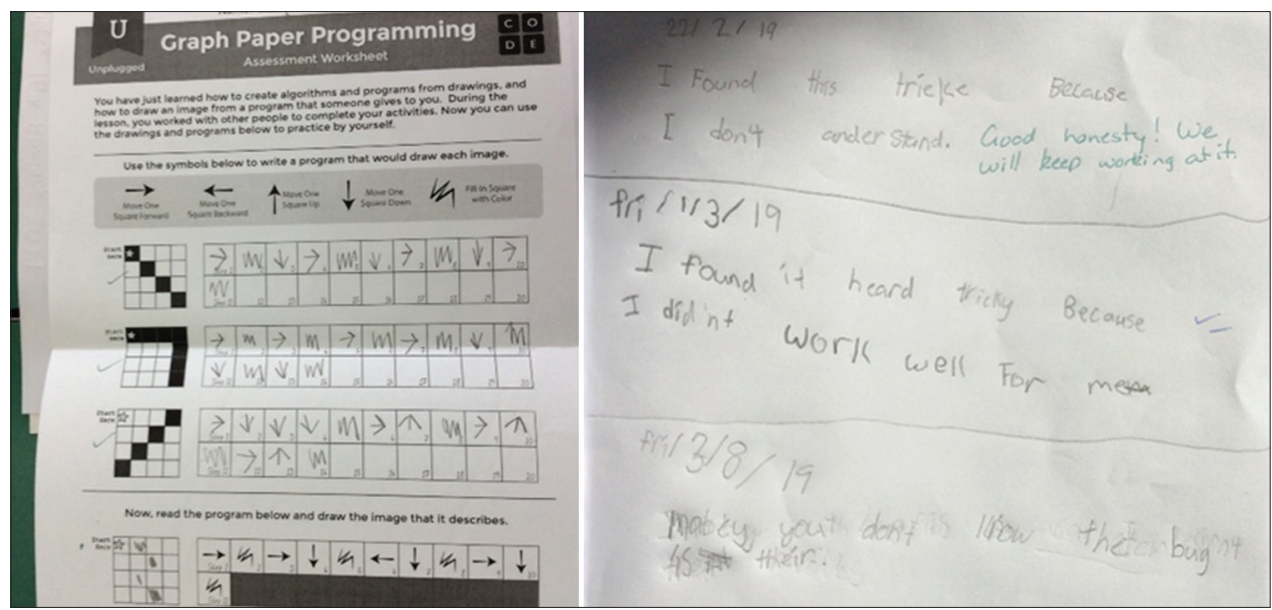

Figure 1: Student assessment examples 
We could take this off-line learning outside or break into groups. Really focusing on the gaps in student's knowledge and ability was what made this work (Diane).

These were useful lesson progressions with resources [Code. org], but the advantage was it was so easy to add extra activities to suit children's interest/level. We would often use a big book to support the learning. It was so encouraging to see the students working to read better so that they could do more online activities (Amy).

\section{CONCLUSIONS - FINAL COMMENTS}

Burstow (2018) highlighted that for lasting and effective teacher PD to take place within a school, consideration must be given to three key factors. First, the methods by which the PD intervention will be delivered. Second, the people involved which includes both the providers and the recipients of the PD. Finally, the working conditions that are currently experienced and the desired conditions intended from the PD. Specifically, using digital technologies in class benefits students through motivation, engagement, independence, personalized learning, critical thinking, and multi-literacies (Earl and Forbes, 2016). Technology allows for new possibilities for enhanced learning and teaching and as such provides opportunities for transformative learning for all students to become critical and connected agents (Berryman and Bishop, 2016). Sadik (2008) noted, "the use of technology can only be effective if teachers themselves possess the expertise to use technology in a meaningful way in the classroom" (p. 487). The School's teachers participating in this study confirmed Sadik's statement. Initial lessons were more familiarization based to allow first the teachers than their students to explore digital tools, toys, and technology. These activities were designed for hands-on and brains-on. Then, through a series of sequenced and scaffolded activities, the lessons gradually integrated Digital Technology with other learning areas of Literacy and Numeracy.

The study ended with the school year on December 16, 2019. As stated, all primary schools must begin the 2020 school year by February 7. In addition, all primary schools are legally required to have digital technology fully implemented into their teaching program. However, no Ministerial directed, funded, or supported PD has been offered to any primary school in New Zealand. As the 2019 school year ended, teachers' final comments noted:

Kids highly motivated was great to see peer mentoring. It was great to have release time to prepare - does not think I could have done it without it! (Diane)

Would start a level down as it got quite hard quite quick for many, however, can see that it would be good for the following year now that we have had a foundation year to see what we can do and more importantly how we can do it (Alice).

All my kids loved it - even those who struggle with motivation and with perseverance when things get tricky - especially those kids made huge strides with these essential skills. The release time was great. Not sure how teachers will manage to get their heads around this without the time to upskill and work with others, this year has made all the difference in being able to actually do this for next year (Barbara).

Trying to bring this new curriculum area in without any of the support we had this year would have been difficult (Principal).

This study highlighted how forms of teacher's emotional, political, and pedagogical work intersected with school-based discourses, curriculum policy, and institutional expectations. These interactions influenced their decisions, beliefs, and actions when teaching a previously unknown area of the curriculum. This study highlighted the assemblage of complex emotional, political, and pedagogical work of the classroom teacher. Schools and classrooms have been referred to as communities of learners (Sewell and St. George, 2016). Sewell and St. George (2016) are writing to, for, and primarily about New Zealand contexts. However, they also highlight those components that are "hallmarks of a community" (p. 241). These hallmarks are agency, belonging, cohesion, and diversity. The participating teachers in this study demonstrated and enacted all of these hallmarks over the length of the 2019 school year as they worked to implement digital technology into their and the School's program.

Most encouraging was how these teachers have been able to work as a collaborative cohort to support each other in this new area. These participating teachers embodied Sewell and St. George (2016) concluding statement, "Curriculum reform and the relative autonomy of New Zealand teachers provide opportunities for them to question assumption as about teaching, engage in professional conversations about learning, and develop their classrooms as learning communities" (p. 256).

\section{REFERENCES}

Armour, K., \& Yelling, M. (2007). Effective professional development for physical education teachers: The role of informal, collaborative learning. Journal of Teaching in Physical Education, 26, 177-200.

Berryman, M., \& Bishop, R. (2016). A culturally responsive pedagogy of relations. In: Fraser, D., \& Hill, M. (Eds.), The Professional Practice of Teaching in New Zealand. $5^{\text {th }}$ ed. United States: Cengage. pp. 180-197.

Burstow, B. (2018). Effective Teacher Development: Theory and Practice in Professional Learning. London, United Kingdom: Bloomsbury Academic.

Carle, E. (1994). The Very Hungry Caterpillar. New York, United States: Philomel Books.

De Bruyckere, P., Kirschner, P.A., \& Hulshof, C.D. (2016). Technology in education: What teachers should know. American Educator, 40(1), 1218,43 .

Deleuze, G., \& Guattari, F. (1988). A Thousand Plateaus: Capitalism and Schizophrenia. Athlone: University of Minnesota Press.

Earl, L., \& Forbes, D. (2016). Connected learners: Transforming learning through ICT. In: Fraser, D., \& Hill, M., (Eds.), The Professional Practice of Teaching in New Zealand. $5^{\text {th }}$ ed. United States: Cengage. pp. 216-239.

Education Counts. (n.d.). Teacher Workforce. Available from: https:// www.educationcounts.govt.nz/statistics/schooling/workforce/teacherworkforce.

ERO. (2012). Evaluation at a Glance: Priority Learners in New Zealand Schools. Available from: https://www.ero.govt.nz/assets/Uploads/ 
Evaluation-at-a-Glance-Priority-Learners-in-New-Zealand-SchoolsAugust-2012.pdf.

Fraser, D. (2013). Curriculum integration. In: Whyte, B., Fraser, D., \& Aitken, V. (Eds.), Connecting Curriculum, Linking Learning. Wellington, New Zealand: NZCER Press. pp. 18-33.

Fraser, D. (2016). The work and artistry of teaching. In: Fraser, D., \& Hill, M., (Eds.), The Professional Practice of Teaching in New Zealand. $5^{\text {th }}$ ed. United States: Cengage. pp. 56-78.

Garbett, D., \& Ovens, A. (2015). Teaching for Tomorrow Today. New Zealand: Edify Ltd.

Garet, M.S., Porter, A.C., Desimone, L., Birman, B.F., \& Yoon, K.S. (2001). What makes professional development effective? Results from a national sample of teachers. American Educational Research Journal, 38(4), 915-945.

Gore, J., Lloyd, A., Smith, M., Julie, B., Ellis, H., \& Lubans, D. (2017). Effects of professional development on the quality of teaching: Results from a randomised controlled trail of quality teaching rounds. Teaching and Teacher Education, 68, 99-113.

Kennedy, M.M. (2016). How does professional development improve teaching? Review of Educational Research, 86(4), 945-980.

Korthagen, F. (2017). Inconvenient truths about teacher learning: Towards professional development 3.0. Teachers and Teaching, 23(4), 387-405.

Means, B., Toyama, Y., Murphy, R., Bakia, M., \& Jones, K. (2009). Evaluation of Evidence-based Practices in Online Learning: A Meta- analysis and Review of Online Learning Studies. United States: United States Department of Education.

Miles, M., \& Huberman, M. (1994). Qualitative Data Analysis: An Expanded Sourcebook. $2^{\text {nd }}$ ed. New York, United States: SAGE.

Ministry of Education. (1995). Technology in the New Zealand Curriculum. Wellington, New Zealand: Learning Media.

Ministry of Education. (2007). The New Zealand Curriculum. Wellington, New Zealand: Learning Media.

Ministry of Education. (2017). Technology in the New Zealand Curriculum. Wellington, New Zealand: Learning Media.

Punch, K.F., \& Oancea, A. (2014). Introduction to Research in Education. $2^{\text {nd }}$ ed. New York, United States: SAGE.

Rubin, H. (2009). Collaborative Leadership: Developing Effective Partnerships for Communities and Schools. $2^{\text {nd }}$ ed. United States: Corwin.

Sadik, A. (2008). Digital storytelling: A meaningful technology-integrated approach for engaged student learning. Educational Technology Research and Development, 56(4), 487-506.

Sewell, A., \& St. George, A. (2016). Developing a community of learners. In: Fraser, D., \& Hill, M., (Eds.), The Professional Practice of Teaching in New Zealand. $5^{\text {th }}$ ed. United States: Cengage. pp. 240-260.

Yurdakul, B. (2015). Perceptions of elementary school teachers concerning the concept of curriculum. Educational Sciences, 15(1), 125-139. 